\title{
Polycyclic Aromatic Hydrocarbons (PAHs) in Muscles of Two Commercial Fish Species from Al-Kahlaa River in Missan Governorate, Iraq
}

\author{
Salih Hassan Jazza ${ }^{1}$, Abdul-Hussain Y. Al-Adhub² and Hamid T. Al-Saad* \\ ${ }^{1}$ Department of Biology, College of Science, University of Missan, Missan, Iraq \\ ${ }^{2}$ Department of Biology, College of Science, University of Basrah, Basrah, Iraq \\ ${ }^{3}$ Department of Marine environmental Chemistry, Marine Science Center, University of Basrah, Basrah, Iraq \\ Email: htalsaad@yahoo.com
}

\begin{abstract}
Al-Kahlaa River is one of main tributaries of the Tigris River in Missan city and rises from northwest side of Amara city and continues to flow in the direction to the east of city center. Two commercial fish species (Liza abu and Carassius auratus) were collected seasonally (autumn, winter, spring and summer) during period from 2012 to 2013 from Al-Kahlaa River in Missan governorate. The concentrations of Polycyclic Aromatic Hydrocarbons (PAHs) in fish muscles were determined in the laboratories of Nihran Omer (South Oil Company in Basrah province), using Gas Chromatography. Total concentrations of PAHs in muscles of L. abu ranged between 2.301 and 16.661 ng.g-1 dry weight during winter and summer respectively and in C. auratus between 1.095 and 8.675 ng. g $^{-1}$ dry weight during winter and summer, respectively. Results of this study revealed that high molecular weight of PAHs were more than low molecular weight in both fish species, and according to ratios of Low molecular weight Polycyclic Aromatic Hydrocarbons (LPAHs) to High molecular weight Polycyclic Aromatic Hydrocarbons (HPAHs), Benzo(a) Anthracene /(Benzo(a) Anthracene+ Chrysene) BaA/(BaA+Chr),Indeno (1,2,3cd) pyrene /(Indeno (1,2,3-cd) pyrene + Benzo (ghi) perylene) InP/(InP+BghiP) and Fluoranthene/Pyrene (FI/Py), they certainly reflected that the PAHs sources in both species are pyrogenic as a main sources and petrogenic as a small part. Also results of this study revealed the presence of seasonal variations in total concentrations of PAHs in both fish species. The study area was generally contaminated with hydrocarbons and continuous consumption of food from this area may pose public health hazards.
\end{abstract}

Keywords: polycyclic aromatic hydrocarbons, PAHs, fish, pollution

\author{
Abstrak \\ Polisiklik Aromatik Hidrokarbon (PAH) pada Otot Dua Spesies Ikan Komersial dari Sungai Al-Kahlaa, \\ Missan, Irak
}

\begin{abstract}
Al-Kahlaa adalah salah satu anak sungai utama Sungai Tigris di kota Missan dari sisi barat laut kota Amara dan terus mengalir ke arah ke timur dari pusat kota. Dua spesies ikan komersial (Liza abu dan Carassius auratus) diperoleh pada musim berbeda (gugur, dingin, semi dan panas) selama periode 2012-2013 dari Al-Kahlaa. Konsentrasi polisiklik aromatik hidrokarbon $(P A H)$ pada otot ikan dianalisis di laboratorium Nihran Omer (South Oil Company di provinsi Basrah), menggunakan Gas Chromatography. Total konsentrasi PAH pada otot L. abu berkisar antara 2,301 dan 16,661 ng. $\mathrm{g}^{-1}$ berat kering pada musim dingin dan musim panas. Sedangkan pada C. auratus antara 1,095 dan 8,675 ng.g-1 berat kering pada musim dingin dan musim panas. Hasil penelitian ini menunjukkan bahwa berat molekul tinggi PAH lebih dari berat molekul rendah pada kedua spesies ikan, dan menurut rasio berat molekul rendah polisiklik aromatik hidrokarbon (LPAHs) untuk berat molekul tinggi polisiklik aromatik hidrokarbon (HPAHs), Benzo (a ) Anthracene / (Benzo (a) Anthracene + Chrysene) BAA / (BAA + Chr), Indeno (1,2,3-cd) pyrene / (Indeno (1,2,3-cd) pyrene + Benzo (ghi) perylene) InP / (InP + BghiP) dan fluoranthen / Pyrene (FI/Py), hal ini mencerminkan bahwa sumber PAH di kedua spesies adalah pirogenik sebagai sumber utama dan petrogenic sebagai bagian kecil. Hasil penelitian ini juga mengungkapkan adanya variasi musiman total konsentrasi PAH di kedua spesies ikan. Daerah penelitian umumnya terkontaminasi dengan hidrokarbon sehingga konsumsi makanan dari daerah ini secara berkelanjutan dapat menimbulkan bahaya kesehatan masyarakat.
\end{abstract}

Kata kunci: polisiklik aromatik hidrokarbon, PAHs, ikan, polusi 


\section{Introduction}

Hydrocarbon compounds enter to fishes tissues either during direct contact, contaminate their gill sand they may eat contaminated food, also the water column may contain toxic and volatile components of oil, therefore might be accumulated in adipose tissues especially aromatic compounds with higher concentrations in their tissues such as glands, brain, gills, liver, gonads and muscles (Ackman et al., 1996). Reaching levels higher than those in the ambient medium, therefore this can affect human in areas that have commercial fisheries (Neff, 1985). Chronic exposure to some chemicals found in oil may cause genetic abnormalities or cancer in sensitive species or suffering from changes in heart beats, respiratory rate, enlarged liver, reduce growth, fin erosion, a variety of biochemical and cellular changes, and reproductive and behavioral responses. (Al-Saad et al., 1997; Deb et al., 2000). Fish eggs and larvae are generally very sensitive to oil pollution, whereas adult fish may have the possibility to avoid the oil contaminated areas, eggs or fish larvae do not have this option and oil may be toxic to fish larvae at low concentrations (Teal and Howarth, 1984; Dragsund et al., 2004). Reynaud and Deschaux (2006) stated that fishes are quite sensitive especially PAHs, leading to several specific and non-specific response by the immune system. The specific responses may involve the production of antibodies, while unspecific responses may involve the effect on increased activities such as lysozyme and/or phagocytosis, these responses may depend on concentrations of PAHs compound and the route of exposure. Also Mcintosh (2009) stated that these compounds impaired fertilization success, and the ages of embryos were negatively correlated with their sensitivity to this pollutant. The present study aimed to estimation of Polycyclic Aromatic Hydrocarbons (PAHs) in muscles of two commercial fish species from Al-Kahlaa River in Missan province.

\section{Materials and Methods}

Fish samples were collected seasonally (autumn, winter, spring and summer) during 2012 and 2013 from Al-Kahlaa River in Missan governorate. Number of Liza abu species were 24, 32, 29 and 23 during autumn, winter, spring and summer, respectively, whereas number of Carassius auratus species were 18, 24, 27 and 31 during autumn, winter, spring and summer, respectively. The age ranged from two to four year for both species. The samples were rinsed thoroughly with distilled water in the laboratory the muscles were cut to small parts and dried in freeze-drier, grounded and sieved using a $63 \mu \mathrm{m}$ metal sieve then placed in clean a glass vial to become ready for analysis. The procedure of Grimalt and Oliver (1993) was used for the extraction of hydrocarbon compounds from fish muscles. The concentrations of PAHs in muscles were determined by using capillary GasChromatography.

\section{Evaluation indices of PAHs pollution}

Many parameters have to be analyzed in order to evaluate the probable origin of Polycyclic Aromatic Hydrocarbons (pyrogenic or petrogenic). These are as follow:

A-ratio of low molecular weight (LMW-PAHs) to high molecular weight (HMW-PAHs). Values greater than one indicate petrogenic origins from crude oil and their derivatives and values less than one are attributed to pyrogenic sources (Vrana et al., 2001).

B-ratio of benzo(a) anthracene / (benzo(a) anthracene + chrysene). Ratio of $\mathrm{BaA} /(\mathrm{BaA}+\mathrm{CHR})$ less than 0.2 implies petrogenic, from 0.2 to 0.35 indicates either petrogenic or pyrogenic origins, and larger than 0.35 implies pyrogenic sources (Guo et al.,2007).

C-ratio of indeno (1,2,3-cd) pyrene /(indeno (1,2,3cd)pyrene + benzo(ghi)perylene). $\operatorname{In} P /(\operatorname{InP}+$ BghiP). Values less than 0.2 implies petrogenic, from 0.2 to 0.5 indicates either petrogenic or pyrogenic origins and higher than 0.5 are implies pyrogenic origins (Guo et al., 2007).

D-ratio of fluoranthene to pyrene (Fl/Py). Values greater than 1 have been used to indicate pyrogenic origins and values less than 1 are attributed to petrogenic source (Qiu et al., 2009).

\section{Results and Discussion}

Results of the present study revealed that the total concentrations of PAHs (ng. $g^{-1}$ ) in muscles of $L$. abu were $2.301,3.007,16.661$ and 4.036 during winter, spring, summer and autumn respectively, Table 1., while in C. auratus were 1.095, 1.289, 8.675 and 5.294 during winter, spring, summer and autumn respectively, Table 2 ., the highest values were recorded during summer, while the lowest values during winter in both species, this seasonal variations may be due to the differences in type of nutrition, fats content, abundant of food, habitat, food habit, size, weight, age, sex and ecological conditions such as temperature, dissolved oxygen (Nasir, 2007; Al-Khatib, 2008; Al-Shwafi, 2008). Temperature has a considerable effect on the ability of microorganisms to degrade PAHs. In addition to that oxygen solubility decreases with increasing 
temperature, which will reduce the metabolic activity of aerobic microorganisms (Al-Khatib, 2008).

The lower molecular weight-PAHs was less than higher molecular weight-PAHs in both species in all seasons, this is due to that the higher molecular weight-PAHs more resistant to degradation processes compared with the lower molecular weight-PAHs (Anyakora and Coker, 2007), in addition to that the fishes have high ability to metabolize the lower molecular weight -PAHs compared with the higher molecular weight-PAHs (Ramalhosa et al., 2012) .Since PAHs can be eliminated out of the body by the fast and effective metabolism through the active Mixed Function Oxidase (MFO) system in fishes (Hylland, 2006).
It can been noticed that levels of $\mathrm{PAH}$ compounds in $L$. abu were more than in C. auratus along the period of study because these fishes have varies ability to accumulate $\mathrm{PAH}$ compounds in their tissues through water and food (Hellou et al., 1993). In order to determine the sources of PAHs in muscles of fishes according to the data (Table 1 and 2). LMW-PAHs/HMW-PAHs ratios were less than one in all seasons ranged from 0.050 to 0.205 and 0.035 to 0.807 in $L$. abu and C. auratus, respectively. $\mathrm{BaA} /(\mathrm{BaA}+\mathrm{Chr})$ ratios were more than 0.35 in both species in all seasons and ranged from (0.44 to 0.913$)$ and (0.379 to 0.807$)$ in L. abu and C. auratus, respectively. The results indicate that the sources of PAHs compounds in both species were pyrogenic (Tolosa et al., 2004; Guo et al., 2007).

Table 1. Seasonal variations of PAHs (ng.g-1 d.w) in Liza abu

\begin{tabular}{|c|c|c|c|c|}
\hline \multirow{2}{*}{ Name compound } & \multicolumn{4}{|c|}{ Seasons } \\
\hline & Winter & Spring & Summer & Autumn \\
\hline Naphthylene & 0.006 & 0.005 & 0.043 & 0.004 \\
\hline Indol & 0.004 & 0.010 & 0.345 & 0.013 \\
\hline 2-methyl naphthylene & 0.015 & 0.026 & 0.116 & 0.024 \\
\hline 1-methyl naphthylene & 0.003 & 0.009 & 0.209 & 0.008 \\
\hline Biphenyl & 0.004 & 0.006 & 0.693 & 0.048 \\
\hline Acenaphthylene & 0.009 & 0.055 & 0.515 & 0.025 \\
\hline Acenaphthene & 0.020 & 0.011 & 0.230 & 0.072 \\
\hline Dibenzofuran +fluorene & 0.043 & 0.143 & 0.137 & 0.019 \\
\hline Anthracene+phenthrathrene & 0.003 & 0.004 & 0.246 & 0.022 \\
\hline Fluoranthene & 0.017 & 0.130 & 1.765 & 0.061 \\
\hline Carbazole & 0.098 & 0.791 & 5.672 & 0.242 \\
\hline Pyrene & 1.060 & 1.223 & 2.260 & 2.692 \\
\hline Benzo(a)anthracene & 0.554 & 0.409 & 2.057 & 0.138 \\
\hline Chrysene & 0.096 & 0.038 & 0.221 & 0.170 \\
\hline Benzo(b+k)fluornanthene & 0.082 & 0.011 & 0.304 & 0.403 \\
\hline Benzo(a) pyrene & 0.011 & 0.006 & 0.347 & 0.019 \\
\hline Indeno (1,2,3-cd)pyrene & 0.063 & 0.015 & 0.321 & 0.010 \\
\hline Dibenzo(a,h)anthracene & 0.196 & 0.064 & 0.767 & 0.052 \\
\hline Benzo(ghi)perylene & 0.009 & 0.042 & 0.406 & 0.005 \\
\hline Total & 2.301 & 3.007 & 16.661 & 4.036 \\
\hline LPAHs & 0.108 & 0.273 & 2.536 & 0.239 \\
\hline HPAHs & 2.175 & 2.603 & 12.358 & 3.734 \\
\hline L/H & 0.050 & 0.105 & 0.205 & 0.064 \\
\hline $\mathrm{BaA} /(\mathrm{BaA}+\mathrm{Chr})$ & 0.851 & 0.913 & 0.902 & 0.44 \\
\hline $\operatorname{lnP} /(\ln P+B g h i P)$ & 0.244 & 0.197 & 0.295 & 0.169 \\
\hline $\mathrm{Fl} / \mathrm{py}$ & 0.016 & 0.106 & 0.781 & 0.023 \\
\hline
\end{tabular}


Table 2. Seasonal variations of PAHs (ng.g-1 d.w) in Carassius auratus.

\begin{tabular}{lcccc}
\hline \multirow{2}{*}{ Name compound } & \multicolumn{4}{c}{ Seasons } \\
\cline { 2 - 5 } & Winter & Spring & Summer & Autumn \\
\hline Naphthylene & 0.010 & 0.008 & 0.008 & 0.003 \\
Indol & 0.023 & 0.012 & 0.047 & 0.003 \\
2-methyl naphthylene & 0.039 & 0.022 & 0.122 & 0.008 \\
1-methyl naphthylene & 0.007 & 0.008 & 0.038 & 0.008 \\
Biphenyl & 0.031 & 0.016 & 0.080 & 0.012 \\
Acenaphthylene & 0.033 & 0.116 & 0.272 & 0.022 \\
Acenaphthene & 0.114 & 0.169 & 0.291 & 0.070 \\
Dibenzofuran +fluorene & 0.040 & 0.122 & 0.234 & 0.015 \\
Anthracene+phenthrathrene & 0.170 & 0.038 & 0.434 & 0.024 \\
Fluoranthene & 0.040 & 0.033 & 0.133 & 0.331 \\
Carbazole & 0.095 & 0.082 & 0.581 & 0.537 \\
Pyrene & 0.118 & 0.047 & 5.054 & 0.262 \\
Benzo(a)anthracene & 0.082 & 0.137 & 0.531 & 2.311 \\
Chrysene & 0.135 & 0.049 & 0.242 & 0.552 \\
Benzo(b+k)fluornanthene & 0.0132 & 0.279 & 0.066 & 0.462 \\
Benzo(a) pyrene & 0.0122 & 0.024 & 0.046 & 0.064 \\
Indeno(1,2,3-cd)pyrene & 0.0321 & 0.020 & 0.011 & 0.193 \\
Dibenzo(a,h)anthracene & 0.0573 & 0.083 & 0.084 & 0.363 \\
Benzo(ghi)perylene & 0.0369 & 0.014 & 0.392 & 0.043 \\
Total & 1.095 & 1.289 & 8.675 & 5.294 \\
LPAHs & 0.471 & 0.516 & 1.530 & 0.171 \\
HPAHs & 0.583 & 0.739 & 7.011 & 4.792 \\
L/H & 0.807 & 0.698 & 0.218 & 0.035 \\
BaA/(BaA+Chr) & 0.379 & 0.737 & 0.686 & 0.807 \\
InP/(InP+BghiP) & 0.359 & 0.198 & 0.122 & 0.347 \\
Fl/py & 0.339 & 0.702 & 0.026 & 1.263 \\
\hline & & & &
\end{tabular}

Table 3. Comparison of concentrations of PAHs compounds in fishes samples from Al-Kahlaa river with their concentrations in other fish species from other areas in Iraq and the world.

\begin{tabular}{lll}
\hline \multicolumn{1}{c}{ References } & \multicolumn{1}{c}{$\begin{array}{c}\text { Concentrations } \\
\left({\left.\mathrm{ng} . \mathrm{g}^{-1}\right) \mathrm{d} . w}^{\prime}\right.\end{array}$} & \multicolumn{1}{c}{ Area } \\
\hline Al-Saadet al.,2006 & $6.78-23,83$ & NW Arabian Gulf \\
Al-Khatib ,2008 & $0.1-92.7$ & Hor Al-Howaiza \\
Al-Khion ,2012 & $12.19-86.48$ & Iraqi coast regions \\
Anayakora and Coker, 2007 & $0.41-39.64$ & Niger Delta /African \\
Da Silva et al., 2006 & $4-53$ & Guanbara bay, Brazil \\
Present study & $1.095-16.661$ & Al-Kahlaa River / Missan province \\
\hline
\end{tabular}

While $\ln \mathrm{P} /(\mathrm{InP}+\mathrm{BghiP})$ ratios ranged from 0.169 to 0.295 and 0.122 to 0.359 in L. abu and C. auratus respectively. The results indicate that the origin of PAHs in $L$. abu and $C$. auratus were pyrogenic and few of them petrogenic. $\mathrm{Fl} /$ py ratios ranged from 0.023 to 0.781 and from 0.026 to
1.261 in $L$. abu and in C. auratus, respectively, this ratio was less than one in both species during all seasons except autumn in C. auratus species, this referred to that the origin of PAHs were petrogenic except in autumn season which was pyrogenic (Chen et al., 2006; Qiu et al., 2009). From the data in table 
3. it can be noticed that the levels of PAHs compounds in the muscles of these fishes were less than their levels in other fishes collected from other regions of Iraq and the world, but these species contain the dangerous compounds in their muscle tissues like Pyrene, Carbazole, Anthracene+ phenthrathrene, Benzo $(b+k)$ fluornanthene and Benzo(a) anthracene because many studies reported that these compounds have a high carcinogenic activity for human and other living organisms (Al-Khion, 2012).

When ingested, PAHs are rapidly absorbed into the gastrointestinal tract due to their high lipid solubility. The rapid absorption of PAHs by human result in a high potency for bio-magnification through food chain. Generally, the greater the number of benzene rings, the greater the toxicity of the PAHs (Cerniglia, 1992). Neff (1982) suggested that consumption of contaminated fish by $\mathrm{PAHs}$ compounds may cause a carcinogenic effects of human. This indicated that the study area was generally contaminated with hydrocarbons and continuous consumption of food from this area may pose public health hazards. There is therefore the need to develop a management plan to ensure that petroleum hydrocarbon contamination of this area is prevented in order to achieve good aquatic life and to avoid possible health problems through the consumption of contaminated fresh water resources such as fishes by the local communities.

\section{Conclusion}

High molecular weight of PAHs were more than low molecular weight in both fish species, and according to the ratios ofLMW-PAHs /HMW-PAHs ,BaA/(BaA+Chr), InP/(InP+BghiP) and $\mathrm{Fl} /$ py the sources of PAHs in fish muscles were pyrogenic as a main and few petrogenic. This indicated that the study area was generally contaminated with hydrocarbons and continuous consumption of food from this area may pose public health hazards, therefore should be preventing the various kinds of industrial and domestic contaminants to be discharged into the river.

\section{Refences}

Ackman, R.G., H. Haras \& S. Zhou. 1996. Salmon lipid storage site and their roles in contamination with water soluble petroleum materials. J. Food Lipids. 3:161-170. doi: 10.1111/j.1745-4522.1996.tb00064.x

Al-Khatib, F.M.H. 2008. Determination the concentration, origin and distribution of hydrocarbons compounds in water, sediments and some biota of Hor AlHowaiza, south of Iraq and their sources. Ph.D., Thesis, College of Science, University of Basrah. 228P. In Arabic.

Al-Khion, D.D. 2012. Distribution of polycyclic nuclear compounds in Iraqi coast regions. Ph.D, Thesis, College of Agriculture, University of Basrah. 171P. In Arabic.

Al-Saad, H.T., Y.Z. Mustafa \& F.J. Al-Imarah. 1997. Distribution of trace metal in the tissue of fish from Shatt Al-Arab Estuary, Iraq. Marina Mesopotamica. 12(1):87-99.

Al-Saad, H.T., H.M. Bedair, H.M.A. Heba \& M.K. Zukhair. 2006. Sources of polycyclic aromatic hydrocarbon (PAHs) in Fish samples from the North West Arabian Gulf and Red Sea Coast of Yemen. Marina Mesopotamica. 21(1):1-13.

Al-Shawafi, N.A.A. 2008. Total petroleum hydrocarbons carcinogens in commercial fish in the Red Sea and Gulf of Aden-Yemen. J. Kau. Mar. Sci. 19:15-28.

Anyakora, C. \& H. Coker. 2007. Assessment of poly nuclear aromatic hydrocarbon content in Four species of fish in the Niger Delta by gas chromatography/ mass spectrometry. African J. Biotech. 6(6):737-743.

Cerniglia, C.E. 1992. Biodegradation of polycyclic aromatic hydro-carbons. Biodegradation. 3: 351-368. doi:10.1007/BF00129093

Chen, S.J., X.J. Luo, B.X., Mai, G.Y. Sheng, J.M. Fu \& E.Y. Zeng. 2006. Distribution and Mass Inventories of Polycyclic Aromatic Hydrocarbons and Organochlorine Pesticides in Sediments of the Pearl River Estuary and the Northern South China Sea. Environ. Sci. Technol. 40(3):709-714. doi:10.1021/es052 060g

Da Silva, D.A., J. Buzitis, M.M. Krahn, M.C. Bícego \& A.M. Pires-Vanin. 2006. Metabolites in bile of fish from Sao Sebasti No channel, SNo Paulo, Brazil, as biomarker of exposure to petrogenic polycyclic aromatic compounds. Mar. Poll. Bull. 52(2):175-183. doi:10.1016/j.marpol bul.2005.08.016

Deb, S.C., T. Avaki \& T. Fukushima. 2000. Polycyclic aromatic hydrocarbon in fish organs. Mar. Poll. Bull. 40(10):882-885. doi:10.1016/SO 025-326X(00)00090-4 
Dragsund, E., V.H. Nilssen, T. Soma, A. Mikkelsen, A. Rudberg \& O.A. Listerud. 2004. Skips trafik klangs Norskekysten-Analyseav Milj. risiko, 2004-0778. Oslo: DNV. 117:2-19 pp.

Grimalt, J.O. \& J. Oliver. 1993. Source input elucidation in aquatic systems by factor and principal component analysis of molecular marker data. Anal. Chem. Acta. 278:159-176. doi:10.1016/0003-2670(93)80094-2

Guo, W., M. He, Z. Yang, C. Lin, X. Quan \& H. Wang. 2007. Distribution of polycyclic aromatic in water, suspended particulate matter and sediment from Daliao River watershed, China. Chemosphere. 68:93-104. doi:10.1016/j. chemosphere.2006.12.072

Hellou, J., C. Upshall, J.F. Payne, S. Naidu \& M.A. Paranjape. 1993. Total unsaturated compounds and polycyclic aromatic hydrocarbons in molluscs collected from waters around Newfoundland. Arch. Environ. Contam. Toxicol. 24:249-257. doi:10.1007/ BF01141355

Hylland, K. 2006. Polycyclic aromatic hydrocarbons (PAHs) ecotoxicology in marine ecosystems, J. Toxicol. Environ. Health A. 69(1):109-123.

Mcintosh, S. 2009. Toxicity of chemically dispersed crude oil early life stages of aquatic herring (Clupea harengus). M.Sc Thesis. Queen's University. 132pp.

Nasir, A.M. 2007. Seasonal variation of the levels of petroleum hydrocarbons, Nickel and Vanadium metals in water, sediments, some Fishes and Shrimps from the Iraqi marine waters. Ph. D. thesis, Basrah Univ., 154P. In Arabic.

Neff , J.M. 1985. Polycyclic Aromatic Hydrocarbons :In: Rand, G.M. and Petrocelly, S.R, Fundamentals of Aquatic Toxicology, Taylor and Francis. pp:416-454.
Neff, J.M. 1982. Polycyclic aromatic hydrocarbons in the aquatic environment and cancer risk to aquatic organisms and man. Pages 385-409 in N.L Richards and B.L. Jackson (eds.). Symposium: carcinogenic polynuclear aromatic hydrocarbons in the marine environment. U.S. Environ. Protection Agency Rep. 600/9-82-013.

Qiu, Y.W., G. Zhang, G.Q. Liu, L.L. Guo, X.D. Li \& O. Wai. 2009. Polycyclic aromatic hydrocarbons (PAHs) in the water column and sediment core of Deep Bay, South China. Est. Coastal Shelf Sci. 83:60-66. doi:10.1016/j.ecss. 2009.03.018

Ramalhosa, M.J., P. Paiga, S. Morais, A.M.M. Sousa, M.P. Gonçalves, C. Delerue-Matos, M.B. Prior \& P. Oliveira. 2012. Analysis of polycyclic aromatic hydrocarbons in fish: optimisation and validation of microwave assisted extraction. J. Food Chem. 35:234-242. doi:10.1016/j.foodchem.2012.04.078

Reynaud, S. \& P. Deschaux. 2006. The effects of polycyclic aromatic hydrocarbons on the immune system of fish: A review. Aquatic Toxicol. 77(2):229-238. doi:10.1016/j.aqua tox. 2005.10 .018

Teal, J.M. \& R.W. Howarth. 1984. Oil spill studies: A review of ecological effects. Environ. Manag. 8(1):27-43. doi:10.1007/BF01867871

Tolosa, I., S Mora, M.R. Sheikholeslami, J.P Villeneuve, J. Bartocci \& C. Cattini. 2004. Aliphatic and aromatic hydrocarbons in coastal Caspian Sea Sediments. Mar. Poll. Bull. 48:44-60. doi:10.1016/S0025-326X (03)00255-8

Vrana, B., A. Pasch \& P. Popp. 2001. Polycyclic Aromatic hydrocarbon concentration and Patterns in sediments and surface water of mansfed region, Saxony. Anhalt, Germany. J. Environ. Monit. 3(6):602-609. 